\title{
Increased levothyroxine requirement in a woman with previously well-controlled hypothyroidism and intestinal giardiasis
}

\author{
Aumento da necessidade de levotiroxina em uma paciente com \\ hipotireoidismo previamente bem-controlado e giardíase intestinal
}

Rafael de Figueiredo Radaeli', Leandro Arthur Diehl'

\section{SUMMARY}

The most common cause of apparent inefficiency or resistance to oral therapy with levothyroxine for hypothyroidism is nonadhesion. However, in some subjects in whom the control of hypothyroidism is extremely difficult, levothyroxine bioavailability defects should be considered. We report here the case of a 57-year-old woman with hypothyroidism that was well-controlled for the previous 6 years but suddenly presented with poor hormonal control and abdominal symptoms, despite repeatedly reporting good compliance to therapy. Adequate control of thyroid function was only obtained after intestinal giardiasis was diagnosed and treated. Ara Bras Endocrinol Metab. 2011;55(1):81-4

\section{SUMÁRIO}

A causa mais comum de aparente ineficácia ou resistência ao tratamento do hipotireoidismo com levotiroxina oral é a má adesão. No entanto, em alguns pacientes nos quais o controle do hipotireoidismo é extremamente difícil, defeitos na biodisponibilidade da levotiroxina devem ser considerados. Relatamos aqui o caso de uma mulher de 57 anos de idade com hipotireoidismo que vinha previamente bem controlado durante 6 anos, mas que, abruptamente, começou a apresentar mau controle hormonal, apesar de insistentemente relatar boa adesão ao tratamento. $\mathrm{O}$ controle adequado da função tireoidiana só foi possível depois que uma giardíase intestinal foi diagnosticada e tratada. Arq Bras Endocrinol Metab. 2011;55(1):81-4

1 Universidade Estadual de Londrina (UEL), Londrina, PR, Brazil

Correspondence to:

Rafael de Figueiredo Radaeli

Rua Marechal Floriano Peixoto, 713 14701-360 - Bebedouro, SP, Brazil rafael_radaeli@hotmail.com

Received on Aug/5/2010 Accepted on Nov/15/2010

\section{INTRODUCTION}

T he failure to adequately control hypothyroidism with oral levothyroxine (L-T4) is a common clinical problem. Nonadhesion is the most common cause, but other conditions can be responsible and should be investigated in selected patients (1). Giardiasis, a common intestinal infection, has been rarely reported to impair the absorption of orally ingested L-T4 (2). We describe here the case of a patient with long-standing hypothyroidism, previously well-controlled with stable doses of L-T4, who abruptly presented poor hormonal control and abdominal symptoms, which only remitted after treatment for giardiasis.

\section{CASE REPORT}

A 57-year-old woman was referred to the Endocrinology public clinic of the city of Londrina (Paraná, Brazil), in November, 2007, due to difficult management of a previously well-controlled hypothyroidism.

The patient informed that her primary care physician had diagnosed her with primary hypothyroidism 9 years earlier, because of her complaints of low energy and depressed humor, and an elevated serum TSH (data not available). She was started on L-T4, with significant clinical and laboratorial improvement. During the next 6 years, she remained asymptomatic with normal TSH levels, and a stable dose of L-T4 (150 mcg), except for a 
marked dose reduction (to $50 \mathrm{mcg}$ ) that was necessary when her medication was withdrawn from the Brazilian market and she was started on a new levothyroxine brand, apparently more potent than the first one. Results for the lab tests are shown in table 1.

About 2 years before referral she noticed that her symptoms (mainly fatigue) had returned, despite that her continuing to take her pills as usual. Her TSH, at that time, had increased to $84 \mathrm{mUI} / \mathrm{mL}$. The patient insistently denied nonadhesion. Several dose adjustments were tried by the primary care physician during the next 13 months, but her TSH only became near-normal when she used a daily dose of $125 \mathrm{mcg}, 2.5$ times greater than her previous usual dosage (Table 1 ).
Interestingly, on that occasion, 9 months before her referral, she also complained of diarrhea and a fecal test was ordered, which resulted positive (specific agent unknown). She was treated with albendazole and in the next few months she was able to gradually reduce her $\mathrm{L}-\mathrm{T} 4$ to $50 \mathrm{mcg} /$ day, but her physician referred her to an Endocrinology specialist due to her frequent need for dose adjustments.

At her first visit to the endocrinologist (November, 2007), she had no symptoms. During a careful interrogation, she reassured the physician that she was taking her levothyroxine every day, at least 30 minutes before breakfast. She was also in use of nifedipine $20 \mathrm{mg}$, after breakfast and supper, for arterial hypertension, and

Table 1. Thyroid function tests and levothyroxine adjustments

\begin{tabular}{|c|c|c|c|c|c|c|}
\hline Date & Complaints & $\begin{array}{l}\text { LT4 dose } \\
\text { in use }\end{array}$ & $\begin{array}{c}\text { TSH (mUl/ } \\
\mathrm{mL})\end{array}$ & $\begin{array}{l}\text { FT4 (ng/ } \\
\text { dL) }\end{array}$ & $\begin{array}{c}H b \\
(g / d L)\end{array}$ & Adjustment of LT4 dose \\
\hline Oct, 1998 & None & 150 mcg & 0.45 & & & Maintained $150 \mathrm{mcg}$ \\
\hline Apr, 2002 & None & 150 mcg & 0.9 & & & Maintained $150 \mathrm{mcg}$ \\
\hline Sep, 2003 & None & 150 mcg & 2.0 & & & Maintained $150 \mathrm{mcg}$ \\
\hline Mar, 2004 & $\begin{array}{l}\text { Levothyroxine brand withdrawn from } \\
\text { market }\end{array}$ & 150 mcg & --- & --- & & $\begin{array}{l}\text { Prescribed a new brand, at the same dose } \\
\qquad(150 \mathrm{mcg})\end{array}$ \\
\hline Oct, 2004 & None & 150 mcg & $<0.01$ & & & Reduced to $50 \mathrm{mcg}$ \\
\hline Jun, 2005 & None & $50 \mathrm{mcg}$ & 0.6 & & & Maintained $50 \mathrm{mcg}$ \\
\hline Oct, 2005 & Fatigue & $50 \mathrm{mcg}$ & 84.4 & & & Increased to $100 \mathrm{mcg}$ \\
\hline Jan, 2006 & None & 100 mcg & 0.09 & & & Reduced to $75 \mathrm{mcg}$ \\
\hline Mar, 2006 & None & $75 \mathrm{mcg}$ & 9.1 & & & Maintained $75 \mathrm{mcg}$ \\
\hline Apr, 2006 & None & $75 \mathrm{mcg}$ & 6.9 & & & Increased to $100 \mathrm{mcg}$ \\
\hline Aug, 2006 & Fatigue & 100 mcg & 6.1 & & & Increased to $125 \mathrm{mcg}$ \\
\hline Jan, 2007 & Fatigue, diarrhea, abdominal pain & $125 \mathrm{mcg}$ & 0.21 & & 13.4 & $\begin{array}{l}\text { Reduced to } 100 \mathrm{mcg} \\
\text { Fecal test }\end{array}$ \\
\hline Feb, 2007 & Diarrhea & $100 \mathrm{mcg}$ & 0.33 & & 13.2 & $\begin{array}{l}\text { Reduced to } 75 \mathrm{mcg} \\
\quad \text { Albendazole }\end{array}$ \\
\hline Apr, 2007 & Diarrhea & $75 \mathrm{mcg}$ & 2.13 & & 12.9 & Maintained $75 \mathrm{mcg}$ \\
\hline Jun, 2007 & None & $75 \mathrm{mcg}$ & 22.4 & & & Maintained $75 \mathrm{mcg}$ \\
\hline Oct, 2007 & None & $75 \mathrm{mcg}$ & 0.14 & & & $\begin{array}{l}\text { Reduced to } 50 \mathrm{mcg} \\
\text { Referral to Endocrinology }\end{array}$ \\
\hline Nov, 2007 & & $50 \mathrm{mcg}$ & --- & --- & 13.7 & $\begin{array}{l}\text { Endocrinology, first visit } \\
\text { Maintained dose; new tests }\end{array}$ \\
\hline Mar, 2008 & $\begin{array}{l}\text { Fatigue, myalgia, muscle cramps, diarrhea } \\
\text { and abdominal pain }\end{array}$ & $50 \mathrm{mcg}$ & $>100$ & 0.67 & & $\begin{array}{l}\text { Increased to } 75 \mathrm{mcg} \\
\text { Fecal test }\end{array}$ \\
\hline May, 2008 & Fatigue, myalgia & $75 \mathrm{mcg}$ & 40.4 & 1.12 & & $\begin{array}{l}\text { Maintained } 75 \mathrm{mcg} \\
\text { Metronidazole/Secnidazole }\end{array}$ \\
\hline Aug, 2008 & None & $75 \mathrm{mcg}$ & 24.8 & 1.01 & & Increased to $88 \mathrm{mcg}$ \\
\hline Jan, 2009 & None & $88 \mathrm{mcg}$ & 6.9 & 1.07 & & Maintained $88 \mathrm{mcg}$ \\
\hline Apr, 2009 & None & $88 \mathrm{mcg}$ & 3.4 & 1.48 & & Maintained $88 \mathrm{mcg}$ \\
\hline Mar, 2010 & None & $88 \mathrm{mcg}$ & 4.4 & 1.15 & 14.0 & Maintained 88 mcg \\
\hline
\end{tabular}


amitriptyline $25 \mathrm{mg}$, at bedtime, for a mild depressive disorder. She denied any other diseases or the use of any other drugs or medications. She was amenorrheic since the age of 51 and had received postmenopausal hormone therapy until the age of 52. On exam, she presented with good general appearance, weight $53 \mathrm{~kg}$ (BMI $22.6 \mathrm{~kg} / \mathrm{m}^{2}$ ), blood pressure $120 / 85 \mathrm{mmHg}$ (seated), pulse $68 \mathrm{bpm}$, with a palpable normal-sized fibroelastic thyroid gland and no other abnormalities.

Her most recent exam was a TSH $0.14 \mathrm{mUI} / \mathrm{mL}$ of 2 months before, when the primary care physician had reduced her dose of L-T4 from $75 \mathrm{mcg}$ to $50 \mathrm{mcg} /$ day. The endocrinologist maintained her last dose $(50 \mathrm{mcg})$ and reinforced the importance of adhesion, asking her to come back in 3 months with new lab tests.

In March 2008, she returned with fatigue, myalgia, muscle cramps, frequent dyspeptic symptoms and diarrhea. She had gained weight $(2 \mathrm{~kg})$, her blood pressure was $140 / 70 \mathrm{mmHg}$, and her new tests revealed very high TSH levels (> $100 \mathrm{~m} \mathrm{UI} / \mathrm{mL}$ ) and a slightly low free T4, along with a small decrease in hemoglobin (Table 1). On interrogation, the endocrinologist found out that she had been treated for giardiasis several years before, when she presented similar clinical picture (she had not reported the use of albendazole on the previous visit a few months before). As the patient insisted that she was adherent, a fecal examination for ova and parasites was ordered and L-T4 was increased to $75 \mathrm{mcg}$.

Two months later, the patient returned reporting remission of muscle cramps and fatigue. Fecal test resulted positive for Giardia lamblia and partial improvement in thyroid function was also noticed (Table 1). The patient was prescribed single-dose secnidazole and 2-week metronidazole PO. After that treatment, a new fecal test resulted negative, and the diarrhea and abdominal pain disappeared.

The dose of L-T4 was increased to $88 \mathrm{mcg}$ a few months later since her TSH still persisted slightly high. After that, the patient presented gradual improvement of thyroid function tests, without further L-T4 dose adjustment and remained asymptomatic for the next 18 months (Table 1).

\section{DISCUSSION}

Adequate intestinal absorption of levothyroxine is essential for the successful management of hypothyroidism. In clinical practice, we often observe patients who remain symptomatic and with elevated TSH levels although they have been prescribed L-T4 in presumably appropriate dosages (about 1.6 to $1.8 \mathrm{mcg} / \mathrm{kg}$ / day in the adult). Noncompliance to therapy ("pseudomalabsorption") is the main reason for this situation $(1,3,4)$. Other possibilities are far less common and include the use of other substances that could interfere with absorption or metabolism of L-T4, or intestinal diseases which could determine true malabsorption of orally ingested thyroid hormone. An extensive review on this matter has been recently published in this Journal by Ward (1).

The first step in the assessment of subjects with poorly controlled hypothyroidism should be to reinforce the importance of adhesion through the daily ingestion of the medication in the fasting state. Some studies show that most patients can be brought to euthyroidism with this simple measure (5).

However, in some cases, TSH levels may persist elevated. In this situation, additional tests can be performed to evaluate if there is an identifiable cause for L-T4 malabsorption. Routinely ordered tests include: anti-gliadin antibodies (for celiac disease), inflammation markers (for inflammatory intestinal disease), lactose tolerance test (for lactose intolerance) $(6,7)$, and, occasionally, anti-T4 antibodies (8). Short bowel syndrome after intestinal or bariatric surgery, hepatic cirrhosis and congestive heart failure can also impair L-T4 intestinal absorption, and should be investigated if there is clinical suspicion $(3,6)$.

In our patient, we decided to search for intestinal parasitosis because of her history of giardiasis and her abdominal complaints (dyspepsia, diarrhea). Fecal test, which confirmed Giardia infection, is the most often used diagnostic test, although its sensitivity is known to be suboptimal (73\% for one sample, and $85 \%$ for three samples) (9).

Giardia lamblia is the most prevalent human intestinal parasitic protist (10). Giardiasis is probably subdiagnosed, but it affects $5 \%-29 \%$ of Brazilian children, more commonly in environments with poor sanitary conditions (11-13). Infected patients may present diarrhea, flatulence, and abdominal pain, but most are asymptomatic $(14,15)$. A known complication of chronic intestinal giardiasis is malabsorption of drugs and nutrients (leading to anemia, growth retardation, and weight loss). The presence of trophozoites activates intestinal $\mathrm{T}$ lymphocytes, which induce inflammatory epithelial damage, shown by diffuse shortening of mi- 
crovilli, maldigestion and malabsorption. In addition, Giardia disrupts epithelial tight junctions and induces enterocitic apoptosis resulting in loss of epithelial barrier, increased intestinal permeability, and diarrhea $(10,15)$. Similar chronic malabsorptive syndromes related to mucosal inflammation have been described with other common intestinal infection agents such as Strongyloides, Clostridium difficile, and Cryptospori$\operatorname{dium}(16)$.

Despite the high frequency of giardiasis, we found only one report of levothyroxine malabsorption associated to Giardia lamblia infection in the literature, describing a patient with persistently high TSH while taking a high dose of L-T4 (2). Our patient presented a similar evolution: she had been euthyroid during 6 years with stable doses of L-T4 but presented TSH elevation and increased requirement of L-T4 coincident with the onset of abdominal symptoms suggestive of Giardia infection, as well as reduction of that requirement soon after antiparasitic treatment, at least in two separate occasions. Metronidazole (for a week), or single-dose secnidazole or tinidazole are the drugs of choice for giardiasis, with $>90 \%$ of cure; other options are albendazole, paromomycin, and nitazoxanide (17).

Although it cannot be totally ruled out, nonadhesion was considered an unlikely explanation based on careful and thorough interrogation, suppression of TSH sporadically observed, and the lack of response to the adhesion-stimulant guidance given by the physician. Drug or food interference with L-T4 absorption was also regarded improbable since serum TSH and L-T4 requirement fluctuated significantly while the patient had not changed her habits. Finally, reduction of L-T4 requirement and stabilization of thyroid function was only possible after eradication of the parasite. Due to the good clinical response, the search for other causes of nonabsorption was deemed unnecessary.

In conclusion, we suggest that giardiasis should also be considered in the assessment of the "difficult patient" with hypothyroidism, after ruling out nonadhesion and use of interfering drugs, specially in areas with high prevalence of the infection (Brazil and other developing countries). Potential candidates to investigation should include patients with previously well-controlled hypothyroidism, with symptoms of giardiasis (weight loss, diarrhea, abdominal pain, anemia) or with personal or family history of giardiasis.

Disclosure: no potential conflict of interest relevant to this article was reported.

\section{REFERENCES}

1. Ward, LS. The difficult patient: drug interaction and the influence of concomitant diseases on the treatment of hypothyroidism. Arq Bras Endocrinol Metab. 2010;54:435-42.

2. SeppelT, Rose F, Schlaghecke R. Chronic intestinal giardiasis with isolated levothyroxine malabsorption as reason for severe hypothyroidism - implications for localization of thyroid hormone absorption in the gut. Exp Clin Endocrinol Diabetes. 1996;104:180-2.

3. Pedrosa W, Santana G. Pseudomalabsorção de levotiroxina - relato de um caso. Arq Bras Endocrinol Metab. 2004;49:308-13.

4. Ain KB, Refetoff S, Fein HG, Weintraub BD. Pseudomalabsortion of levothyroxine. JAMA. 1991;266:2118-20.

5. Bagattoli RM, Vaisman M, Lima JS, Ward LS. Estudo de adesão ao tratamento do hipotiroidismo. Arq Bras Endocrinol Metab. 2000;44:483-7.

6. Singh N, Hershman JM. Interference with the absorption of levothyroxine. Curr Opin Endocrinol Diabetes. 2003;10:347-52.

7. Muñoz-Torres M, Varsavsky M, Alonso G. Lactose intolerance revealed by severe resistance to treatment with levothyroxine. Thyroid. 2006;11:1171-3.

8. Suzuki Y, Takeshita E, Kano S, Hirata S, Sato S. Impaired intestinal absorption of thyroid hormone in a case of Hashimoto's disease with anti-T3 and anti-T4. Nippon Naibunpi Gakkai Zasshi. 1982:58:1487-97.

9. Goka AK, Rolston DD, Mathan VI, Farthing MJ. The relative merits of faecal and duodenal juice microscopy in the diagnosis of giardiasis. Trans R SocTrop Med Hyg. 1990;84:66-7.

10. Buret AG. Pathophysiology of enteric infections with Giardia duodenalis. Parasite. 2008;15:261-5.

11. Pereira MGC, Atwill ER, Barbosa AP. Prevalence and associated risk factors for Giardia lamblia infection among children hospitalized for diarrhea in Goiânia, Goiás State, Brazil. Rev Inst Med Trop S Paulo. 2007;49:139-45.

12. Carvalho-Costa FA, Gonçalves $A Q$, Lassance SL, Silva Neto LM, Salmazo CAA, Bóia MN. Giardia lamblia and other intestinal parasitic infections and their relationships with nutritional status in children from Brazilian Amazon. Rev Inst Med Trop S Paulo. 2007;49:147-53.

13. Ferreira MU, Ferreira CS, Monteiro CA. Tendência secular das parasitoses intestinais na infância na cidade de São Paulo (19841996). Rev Saúde Públ (S Paulo). 2000;34:73-82.

14. Castro H. Giardíase: considerações práticas. Rev Port Clín Geral. 2001;17:57-61.

15. Ali SA, Hill DR. Giardia intestinalis. Curr Opin Infect Dis. 2003;16:453-60.

16. Aubry P. Malabsorption syndrome and intestinal parasitosis. Med Trop (Mars). 1983;43:317-24.

17. Gardner TB, Hill DR. Treatment of giardiasis. Clin Microbiol Rev. 2001;14:114-28. 